\title{
Rabbiteye Blueberry Postharvest Fruit Quality and Stimulation of Ethylene Production by 1-Methylcyclopropene
}

\author{
Dan D. MacLean ${ }^{1}$ and D. Scott NeSmith \\ Department of Horticulture, University of Georgia, 4604 Research Way, \\ Tifton, GA 31793
}

Additional index words. ethylene, firmness, storage

\begin{abstract}
A postharvest 1-methylcyclopropene (1-MCP) treatment was evaluated for its ability to maintain firmness and delay the ripening of rabbiteye blueberries. Three cultivars, Austin, Brightwell, and Premier, were harvested by hand from the UGA Alapaha Blueberry Farm and treated overnight with $1 \mu L \cdot L^{-1} 1-M C P$ as field heat was being removed $\left[0\right.$ to $1{ }^{\circ} \mathrm{C}, 90 \%$ to $95 \%$ relative humidity (RH)]. Fruit were evaluated for firmness, total soluble solids (TSS), total acidity (TA), ethylene production, and other quality attributes at 0,1 , and 2 weeks after harvest as well as 1 or 4 days post-removal evaluations at room temperature $\left(\approx 21^{\circ} \mathrm{C}\right)$. In general, the 1 -MCP treatment resulted in the stimulation of ethylene production in all three cultivars but had minimal effect on TSS and TA content. Furthermore, the treatment resulted in an accelerated loss of firmness in 'Brightwell'. The lack of inhibition of fruit ripening likely related to the fact that blueberries were harvested, and subsequently treated with 1-MCP, at a postclimacteric stage of development. Based on current results, more information is required regarding ethylene production during rabbiteye blueberry fruit maturation before establishing a 1-MCP treatment recommendation for use by the rabbiteye blueberry industry.
\end{abstract}

Maintaining fruit firmness is an important consideration during the postharvest handling and storage of rabbiteye blueberry (Vaccinium virgatum Aiton). Soft fruit can result from poor cultivar characteristics, harvest maturity, harvest method (hand or machine), handling during transport, grading and packaging as well as storage temperature and duration. Regardless of the source, soft fruit will often culminate in the increased spread and sporulation of saprophytic fungal pathogens during subsequent storage and marketing periods (Sanford, 1991; Miller, 1984; Ballinger, 1978; Hudson, 1981). Even if the fruit appears visually sound, wholesalers and consumers consider soft fruit to be unacceptable (Rohrbach and Mainland, 1987). As a result, soft fruit contribute to poor postharvest quality and a substantially abbreviated marketing period.

Blueberries are considered highly perishable and have a moderate respiration rate. In south Georgia, rabbiteye blueberry harvest occurs in June, where daytime temperatures routinely exceed $30{ }^{\circ} \mathrm{C}$ for 6 to $8 \mathrm{~h} \cdot \mathrm{d}^{-1}$, and $\mathrm{RH}$ often in excess of $80 \%$. Tight packing of these dark-pigmented fruit in lugs can often result in temperatures much greater. Fruit must

\footnotetext{
Received for publication 1 Feb. 2011. Accepted for publication 25 June 2011

We gratefully acknowledge the financial support of the USDA (Award No. 2008-34611-19375) and AgroFresh, Inc. We also thank Gunawati Gunawan, Shane Tawzer, and Brantley Morris for their technical support.

${ }^{1}$ To whom reprint requests should be addressed; e-mail dmaclean@uga.edu.
}

be cooled promptly after harvest to maintain fruit quality. Tetteh et al. (2004) found that firmness loss in blueberries began immediately after harvest and that the degree of firmness loss was correlated with the time delay between harvest and cooling.

Blueberries have historically been classified as climacteric fruit (El-Agamy et al., 1982). However, unlike many climacteric fruit that can be harvested at a pre-climacteric stage of development and ripened in a controlled manner closer to the market, blueberries are harvested near full ripeness and will not improve in quality during handling and storage. A notable exception is where antioxidant content, an important quality parameter, can increase during storage in select cultivars (Connor et al., 2002). However, in general, blueberry quality, including firmness, will decrease after harvest. Any technology that could assist with the maintenance of firmness after harvest would be of great benefit to the blueberry industry.

A postharvest application of 1-MCP is very effective at inhibiting loss of quality in numerous fruits and vegetables (Watkins, 2006). A treatment of 1-MCP reduces the perception of ethylene by competitively binding to the ethylene receptors in the tissue (Sisler et al., 1996; Sisler and Serek, 1997). Firmness, an important quality parameter, is retained in numerous crops, including apple (Malus domestica Borkh.) (Fan et al., 1999), avocado (Persea americana Mill) (Feng et al., 2000), apricots (Prunus armeniaca L.) and plums (Prunus domestica L.) (Dong et al., 2002), pear (Pyrus communis L.) (Baritelle et al., 2001), and tomato (Lycopersion escu- lentum L.) (Hoeberichts et al., 2002), after an exposure to 1-MCP. The majority of these studies also reported a highly significant reduction in the rate of ethylene production.

To the best of the authors' knowledge, there are no published reports on the use of 1-MCP for maintaining blueberry fruit firmness. However, it was demonstrated that a moderate treatment rate of 1-MCP did not affect the percent marketable fruit of 'Burlington' or 'Coville' highbush blueberries (Delong et al., 2003). Thus, the objective of this study was to establish the efficacy of a 1-MCP treatment for the maintenance of postharvest quality in rabbiteye blueberry cultivars.

\section{Materials and Methods}

Harvest. Fruit were harvested from the University of Georgia Alapaha Blueberry Research Farm from an 8-year-old block of 'Austin', 'Brightwell', and 'Premier' bushes. Within a row of 40, 10 bushes in triplicate were harvested, leaving three nonharvested plants between repetitions and two non-harvested plants at row ends. Fruit were harvested by hand into pails on 2 June 2009 ('Premier', 60\% blue) or 8 June 2009 ('Austin', $50 \%$ blue; 'Brightwell', $60 \%$ blue), transferred into lugs, and held at $14{ }^{\circ} \mathrm{C}$ in a custom-built insulated walk-in mobile cold storage unit [inside dimensions (cm): 168 wide $\times 180$ deep $\times 147$ high] cooled by a high-capacity air conditioner (18,500 BTU; Frigidaire, Augusta, GA). After harvest was complete, fruit were transported to the Vidalia Onion Research Laboratory, located at the University of Georgia, Tifton, GA, where fruit were sorted into $550 \mathrm{~mL}$ (1-pint) clamshells and placed directly into cold storage rooms (0 to $1{ }^{\circ} \mathrm{C}, 90 \%$ to $95 \% \mathrm{RH}$ ).

1-Methylcyclopropene and storage treatments. After placement in cold storage, fruit from each repetition were treated overnight (12 h) with $1 \mu \mathrm{L} \cdot \mathrm{L}^{-1} 1-\mathrm{MCP}$ (SmartFresh ${ }^{\mathrm{TM}}$, supplied by AgroFresh, Springhouse, PA) in inverted 117-L containers (Rubbermaid Roughneck Tote \#2244) sealed with water. The 1-MCP and activator tablets, along with the activator solution, were added to a battery-operated fan supplied by AgroFresh in accordance with their suggested treatment protocol. Non-treated control fruit were placed in three identical, inverted, sealed containers. After completion of the 1-MCP treatment, a subset of the repetitions was removed and warmed to room temperature $\left(21^{\circ} \mathrm{C}\right.$; Week $0)$, whereas the remaining fruit were maintained at cold storage conditions $\left(0\right.$ to $1{ }^{\circ} \mathrm{C}$, 90 to $95 \% \mathrm{RH})$. During warming $(2 \mathrm{~h})$, clamshells were stacked vertically in front of household fans to prevent moisture from condensing on the fruit surface. Subsequent samples were removed from storage and warmed in a similar manner 1 and 2 weeks after harvest.

Firmness. Flesh firmness $\left(\mathrm{g} \cdot \mathrm{mm}^{-1}\right)$ and size ( $\mathrm{mm} /$ diameter) were monitored 1 and $4 \mathrm{~d}$ after each removal $(0,1$, or 2 weeks) from storage at room temperature $\left(\approx 21{ }^{\circ} \mathrm{C}\right)$ using a Bioworks FirmTech II fruit firmness tester 
(Bioworks Inc., Wamego, KS) equipped with a 25-fruit sampling plate. A sample of 50 fruit was assessed for each repetition. Fruit were placed equatorially to minimize firmness variation resulting from calyx or blossom end characteristics. Force-deformation values $\left(\mathrm{g} \cdot \mathrm{mm}^{-1}\right)$ were used to measure the firmness with the maximum and minimum forces of the load cell set to $250 \mathrm{~g}$ and $50 \mathrm{~g}$, respectively. All data collection and storage were controlled by BioWorks software program (Version 3 ).

Titratable acids and soluble sugars content. Juice was extracted from a subsample of fruit $(\approx 20 \mathrm{~g})$ using a Waring Commercial juice processor (Model 6001c; New Hartford, CT). An aliquot of the juice was then centrifuged using a benchtop microcentrifuge (Eppendorf 5418 , Hamburg, Germany) at $16,000 \mathrm{~g}$ for $2 \mathrm{~min}$. A $100-\mu \mathrm{L}$ sample from the resulting supernatant was used for determination of TSS content (\%) using a digital handheld refractometer (BrixStix; Cole Parmer, Livermore, CA) calibrated with distilled water. For determination of TA content, $\approx 1 \mathrm{~g}$ of supernatant was diluted 25:1 with distilled water and titrated with $0.1 \mathrm{M} \mathrm{NaOH}$ to a $\mathrm{pH}$ of 8.2 using a DL-15 automatic titrator (Mettler Toledo, Switzerland), where acidity (expressed in citric acid equivalents) and initial $\mathrm{pH}$ were recorded.

Ethylene production. After each fruit removal $(0,1$, and 2 weeks), ethylene production was monitored for $4 \mathrm{~d}$ at room temperature $\left(21^{\circ} \mathrm{C}\right)$. Approximately $100 \mathrm{~g}$ of fruit per repetition were placed into a 0.5 -pint canning jar (Ball, Daleville, IN) and sealed with lids modified with a rubber septum needle sampling port. Fruit were sealed for $\approx 6 \mathrm{~h}$ before a $1-\mathrm{mL}$ headspace sample was withdrawn using a gas-tight $1000-\mu \mathrm{L}$ Hamilton syringe and injected into an Agilent 7890A gas chromatograph (Foster City, CA) equipped with a capillary electronic pressure control (EPC) direct injection port $\left(50^{\circ} \mathrm{C}\right)$ running in split mode $(20: 1)$, an HP-Plot-Q column $(15 \mathrm{~m} \times 0.32 \mathrm{~mm} \times 20$ $\left.\mu \mathrm{m} ; 40{ }^{\circ} \mathrm{C}\right)$, and a flame ionization detector with EPC $\left(225^{\circ} \mathrm{C}\right)$. Helium was used as a carrier gas at a constant linear flow rate of 2.66 $\mathrm{mL} \cdot \mathrm{min}^{-1}$. Data collection was at a sample rate of $50 \mathrm{~Hz}$, all controlled by Chemstation (rev. B.03.01). Ethylene content was determined by comparison of retention time and peak area to a certified standard $\left(5.144 \mu \mathrm{L} \cdot \mathrm{L}^{-1}\right.$; Airgas South, Atlanta, GA).

Statistical analysis. The treatment effects were analyzed using PROC Mixed in SAS Version 9.2 and SAS Enterprise Guide 4.2 (Cary, NC) at a significance level of $P<0.05$. Fixed effects were cultivar, treatment, removal, and shelf, whereas replication was designated a random effect.

\section{Results and Discussion}

Of all the cultivars, across all storage, shelf life, and 1-MCP treatment effects, 'Brightwell' had the greatest firmness with a measurement of $221.7 \mathrm{~g} \cdot \mathrm{mm}^{-1}$, whereas 'Austin' and 'Premier' followed with scores of 171.0 and 157.5, respectively (Table 1). All cultivars were harvested at an appropriate maturity for short-term storage (50\% to $60 \%$ blue). Other studies investigating the firmness of rabbiteye blueberries have shown that 'Brightwell' had the highest firmness, the lowest postharvest weight loss, and was most resistant to postharvest deterioration when compared with 'Powderblue' and 'Tifblue' (Barrios et al., 2008) and other cultivars (NeSmith et al., 2005). It is also identified as a cultivar that may be appropriate for machine harvesting as a result of the minimal firmness difference between hand- and machine-harvested fruit (NeSmith et al., 2002).

There was very little difference in TSS or TA content among cultivars. 'Premier' had slightly higher soluble sugars and higher TA. However, the sugar-to-acid ratio was virtually identical for all cultivars. During the 2 weeks of storage, the soluble sugars content increased in all cultivars, whereas the TA decreased (Table 1). A similar trend was observed over a 45-d storage period, in which 'Tifblue' and 'Bluegem' both increased $\approx 1 \%$ in TSS content over the duration of the storage (Basiouny and Chen, 1988; Graddick et al., 1986). However, the increasing trend in TSS content did not continue once the fruit were removed from low-temperature storage. This is likely related to the increase in rate of ripening and the use of the sugars for respiration.

In contrast, TA trended in the opposite direction to TSS. It was observed that acidity decreased during cold storage but increased when fruit were permitted to ripen at room temperature up to $4 \mathrm{~d}$. These changes are likely related to selective inhibition of the primary respiratory pathway enzymes during cold storage. A decreasing trend in TA content has been reported previously (Zheng et al., 2003). As a consequence, the sugar-to-acid ratio increased during cold storage but tended to decrease as fruit were removed to room temperature. It was also observed that the 1-MCP treatment resulted in a significant increase in TSS without

Table 1. Postharvest quality parameters for 'Austin', 'Brightwell', and 'Premier' rabbiteye blueberry cultivars after a postharvest treatment of $1 \mu \mathrm{L} \cdot \mathrm{L}^{-1} 1$-MCP followed by 0,1 , or 2 weeks of storage $\left(0\right.$ to $1{ }^{\circ} \mathrm{C}, 90 \%$ to $95 \%$ relative humidity) and a simulated shelf life of 1 or $4 \mathrm{~d}$ at room temperature $\left(\approx 21{ }^{\circ} \mathrm{C}\right) .{ }^{z}$

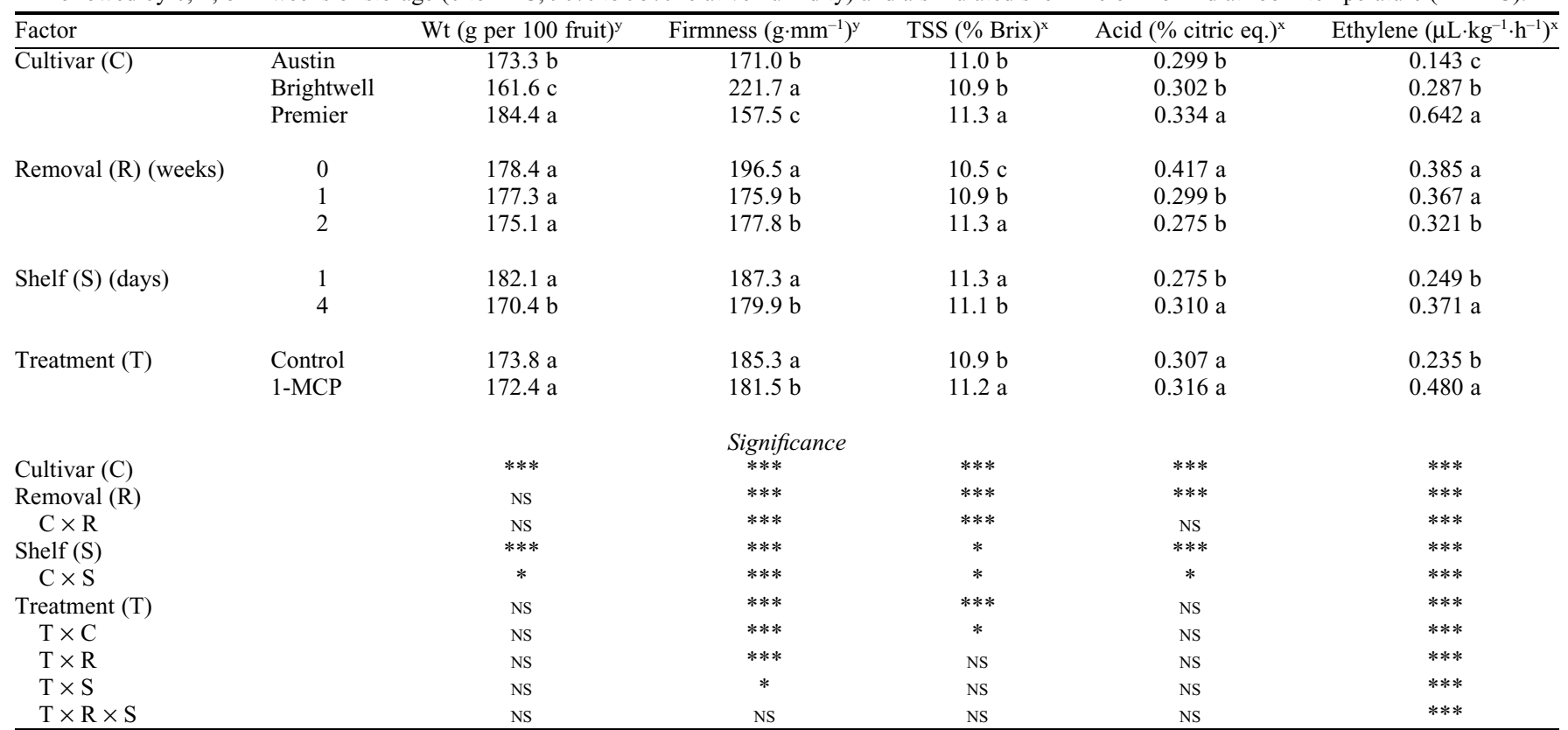

${ }^{2}$ Values for each factor within the same column followed by different letters are significantly different at $P<0.05$. ND, $*, * *, * * *$ non-significant and significant at $P=0.05,0.01$, or 0.001 , respectively.

${ }^{y}$ Values are a mean of three replications of 100 fruit each.

${ }^{\mathrm{x}}$ Values are a mean of three replications of a combined sample of $20 \mathrm{~g}$ each.

TSS $=$ total soluble solids. 
having any influence on the change in TA content. It has been observed previously that a 1-MCP treatment can increase the TSS content of apple (Fan et al., 1999) and onion (Allium cepa L.) (Chope et al., 2007), although the mechanism is still unknown.

Across all treatment effects, the loss in firmness was greatest in 'Brightwell' with a $16 \%$ drop in the first week after harvest. However, no further loss in firmness occurred in the second week of storage. In a similar manner, 'Austin' also displayed a significant drop $(9 \%)$ in the first week of storage, whereas firmness loss in 'Premier' was unaffected by storage. With respect to the 1-MCP treatment, no beneficial effect on the retention of firmness was observed in either 'Austin' or 'Premier', whereas an accelerated rate of firmness loss was observed in 'Brightwell'. This accelerated rate of loss resulted in firmness being significantly and consistently $5.5 \%$ lower in the 1-MCP-treated fruit than in the untreated control fruit.

Loss of firmness in response to the 4-d shelf life period was also observed in 'Brightwell'. However, similar losses were not observed in the other two cultivars, which stayed relatively stable during the $4 \mathrm{~d}$ of post-storage evaluations. Similar to the trend observed after removal from storage, the 1-MCP treatment resulted in an apparent acceleration in the loss of firmness in 'Brightwell' during the simulated shelf life period. In this case, the significant loss of firmness in response to the 1-MCP treatment after Day 1 was only $3.6 \%$ lower, but the differential increased up to $7.5 \%$ by Day 4 . It is unclear if the absence of any storage or 1-MCP treatment effects in 'Austin' and 'Premier' were the result of the lower initial firmness.

There were significant differences in ethylene production rates among the three cultivars. In general, 'Premier' had the highest rate, at $\approx 0.6 \mu \mathrm{L} \cdot \mathrm{kg}^{-1} \cdot \mathrm{h}^{-1}$. The rate of production in 'Brightwell' was approximately half that of 'Premier' with 'Austin' being half that again. Ethylene production varied little in response to the cold storage treatment with the exception of 'Premier', which demonstrated a sharp decline in production between 1 and 2 weeks of storage (Fig. 1). In contrast, ethylene production increased for the first 2 to $3 \mathrm{~d}$ after removal from cold storage for all cultivars (Fig. 2).

The postharvest 1-MCP treatment resulted in significantly higher rates of ethylene production in all cultivars. During the 2 weeks of cold storage, ethylene production nearly doubled in response to the 1-MCP treatment (Fig. 1). This trend occurred irrespective of the cultivar, and rates of ethylene production were nearly parallel with rates of production observed in untreated fruit. In a similar manner, the rates of ethylene production in 1-MCP-treated fruit were significantly and consistently higher than untreated fruit during the 4-d simulated shelf life period (Fig. 2). These observations suggest that the 1-MCP treatment resulted in the promotion of ethylene production. This observation is in disagreement with the majority of studies reporting

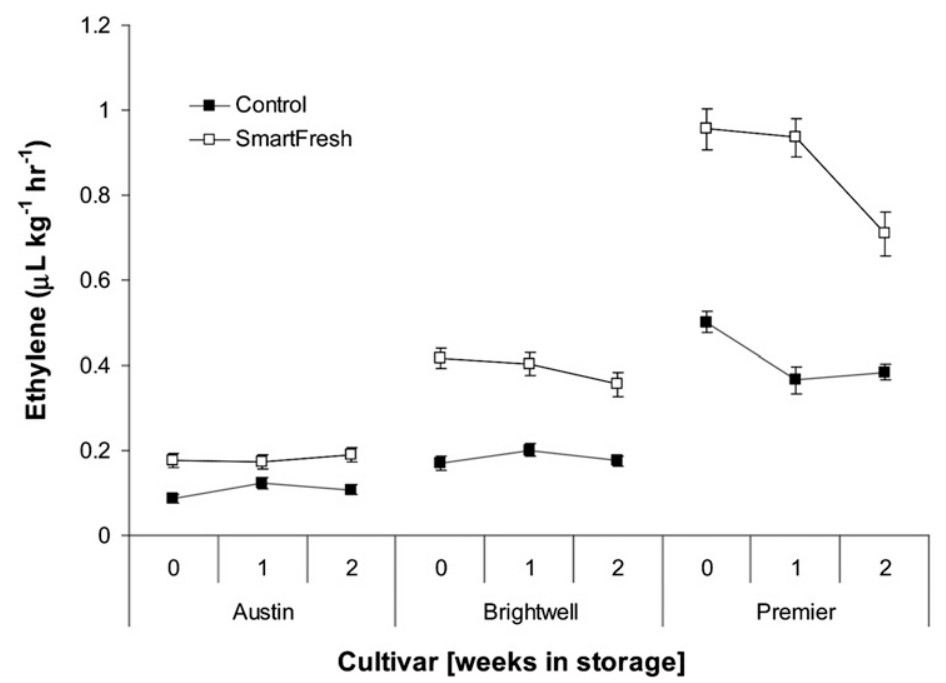

Fig. 1. Ethylene production of 'Austin', 'Brightwell', and 'Premier' rabbiteye blueberry after a $1 \mu \mathrm{L} \cdot \mathrm{L}^{-1}$ 1 -MCP postharvest treatment during a 2 -week $(0,1$, or 2$)$ storage $\left(0\right.$ to $1{ }^{\circ} \mathrm{C}, 90 \%$ to $95 \%$ relative humidity) averaged over all shelf effects. Fruit were removed from storage at each interval and warmed to $\approx 21{ }^{\circ} \mathrm{C}$ for $2 \mathrm{~h}$ before evaluation $(P<0.05) .1-\mathrm{MCP}=1$-methylcyclopropene.

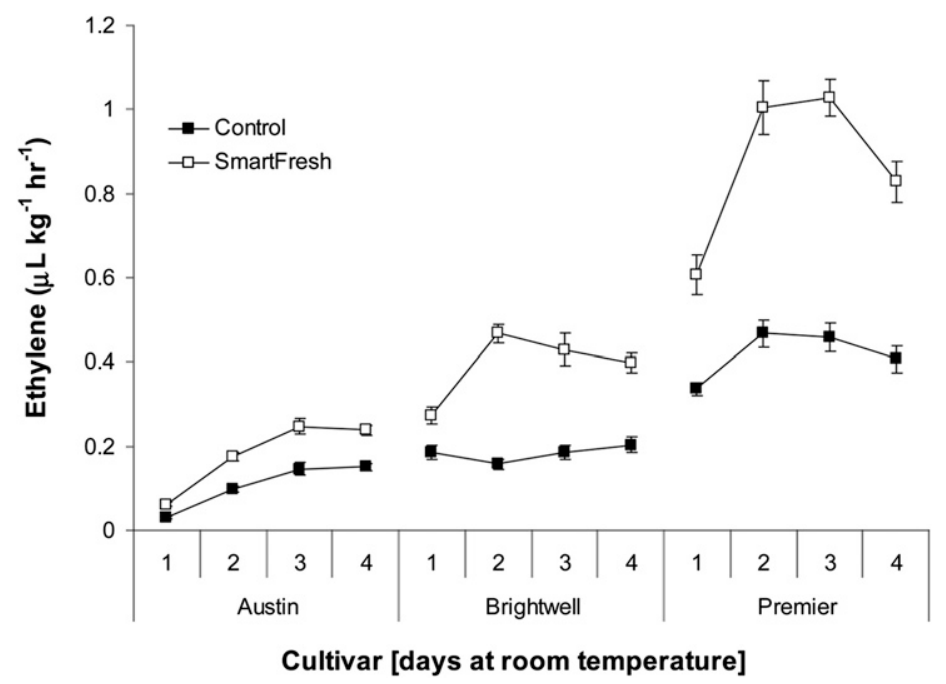

Fig. 2. Ethylene production of 'Austin', 'Brightwell', and 'Premier' rabbiteye blueberry after a postharvest treatment of $1 \mu \mathrm{L} \cdot \mathrm{L}^{-1} 1-\mathrm{MCP}$ during a 4 -d post-storage shelf evaluation at room temperature $\left(\approx 21{ }^{\circ} \mathrm{C}\right)$ averaged over all removal effects $(P<0.05)$. 1-MCP $=1$-methylcyclopropene.

on the effect of 1-MCP in fruit, in which inhibition in the rate of ethylene production is typically observed (Watkins, 2006).

Although a treatment of 1-MCP generally results in an inhibition of ethylene production, this is not always the case. Although the observed increases were highly dependent on stage of maturity and 1-MCP treatment concentration, increases have been observed in other crops, including avocado (Jeong et al., 2003), grapefruit (Citrus $\times$ paradisi Macfad.) (Mullins et al., 2000), and strawberry (Fragaria $\times$ ananassa L.) (Tian et al., 2000). A study investigating the effect of 1-MCP treatments ranging from 0.01 to $1.0 \mu \mathrm{L} \cdot \mathrm{L}^{-1}$ on banana found that irrespective of the treatment concentration, ethylene concentrations inside a polyethylene bag were higher than the control (Jiang et al., 1999). Similarly, a 1MCP treatment was also found to increase ethylene production in mature green banana (Golding et al., 1998). A study exploring the potential application of 1-MCP on fresh-cut tomato found that 1-MCP treatment increased ethylene production $39 \%$ over untreated control slices, but only at the lowest $\left(5^{\circ} \mathrm{C}\right)$ storage temperature (Jeong et al., 2004). All these studies suggest that the 1-MCP treatment compromises the autocatalytic ethylene regulatory mechanism in some manner.

Blueberries are climacteric fruit (ElAgamy et al., 1982; Lipe, 1978). However, unlike some other classical ethylene climacteric fruits (e.g., apple, banana, pear, or tomato), which are harvested pre-climacteric, blueberry fruit are harvested at the post-climacteric rise, when fruit are close to ripe and transitioning into the senescence stage of development. Other studies observed that the highest levels of ethylene production occurred when fruit 
were between mature green and late pink stages of development, which occurs anywhere between 2 to $6 \mathrm{~d}$ before commercial harvest (Suzuki et al., 1997). However, ripe fruit will still respond to postharvest exogenous applications of ethylene, resulting in an increase in the rate of ripening (Janes et al., 1978), although this artificially induced physiological response may not be relevant to the natural ripening processes of rabbiteye blueberry.

It has been suggested that the control of ethylene is critical to maintain acceptable quality of blueberry during extended periods of cold storage (Basiouny and Chen, 1988). As a consequence, multiple different ethylene synthesis and action inhibitors have been tested previously with beneficial results achieved up to $56 \mathrm{~d}$ of storage in 'Tifblue' and 'Gardenblue' rabbiteye blueberries (Graddick et al., 1986). However, the limited application of these technologies to a commercial setting, as a result of cost, complicated application procedures, or toxicity, has resulted in these chemistries being largely ignored by industry. A treatment of 1-MCP has the potential to circumvent many of those limitations as has been observed in some other fruit and vegetable fruit systems. However, this study has demonstrated that treating blueberry fruit with 1-MCP at horticultural maturity, the ethylene antagonist will not adequately suppress the action of ethylene or maintain postharvest quality of rabbiteye blueberry. The role of ethylene and its associated biosynthetic and signal transduction pathways can vary between different fruit crops or can even vary within a crop, as was recently reported in plum (ElSharkawy et al., 2008). In blueberry, it is not known whether positive or negative autocatalytic ethylene mechanisms are in place to regulate fruit development. Thus, we are currently investigating the expression of ethylenerelated genes to understand the coordination of ripening events and correlation to the presence or absence of ethylene in ripening rabbiteye blueberry tissues.

\section{Conclusion}

A postharvest application of 1-MCP resulted in the stimulation of ethylene production, accelerated rate of firmness loss, and an increase in TSS. However, the specific role of ethylene during blueberry fruit ripening is largely unknown. As a consequence, further studies are required to determine the potential application of 1-MCP for use in the maintenance of firmness and postharvest quality in rabbiteye blueberry.

\section{Literature Cited}

Ballinger, W.E., E.P. Maness, and W.F. McClure. 1978. Relationship of stage of ripeness and holding temperature to decay development of blueberries. J. Amer. Soc. Hort. Sci. 103:130134.
Baritelle, A.L., G.M. Hyde, J.K. Fellman, and J. Varith. 2001. Using 1-MCP to inhibit the influence of ripening on impact properties of pear and apple tissue. Postharvest Biol. Technol. 23: 153-160.

Barrios, A.N., E.S. Chavez, J.R. Vega, and D.S Nesmith. 2008. Postharvest quality of blueberry cultivars (Vaccinium sp.) as affected by prestorage time and temperatures. Agricultura Técnica en México. 34:453-457.

Basiouny, F.M. and Y. Chen. 1988. Effects of harvest date, maturity and storage intervals on postharvest quality of rabbiteye blueberry ( $\mathrm{Vac}$ cinium ashei Reade). Proc. of the Florida State Horticultural Society. 101:281-284.

Chope, G.A., L.A. Terry, and P.J. White. 2007. The effect of 1-methylcyclopropene (1-MCP) on the physical and biochemical characteristics of onion cv. SS1 bulbs during storage. Postharvest Biol. Technol. 44:131-140.

Connor, A.M., J.J. Luby, J.F. Hancock, S. Berkheimer, and E.J. Hanson. 2002. Changes in fruit antioxidant activity among blueberry cultivars during cold-temperature storage. J. Agr. Food Chem. 50:893-898

Delong, J.M., R.K. Prange, C. Bishop, P.A. Harrison, and D.A.J. Ryan. 2003. The Influence of 1-MCP on shelf-life quality of highbush blueberry. HortScience 38:417-418.

Dong, L., S. Lurie, and H.-W. Zhou. 2002. Effect of 1 -MCP on ripening of 'Canino' apricots and 'Royal Zee' plums. Postharvest Biol. Technol. 24:135-145.

El-Agamy, S.Z.A., M.M. Aly, and R.H. Biggs 1982. Fruit maturity as related to ethylene in 'Delite' blueberry. Proc. of the Florida State Horticultural Society. 95:245-246.

El-Sharkawy, I., W.S. Kim, S. Jayasankar, A.M. Svircev, and D.C.W. Brown. 2008. Differential regulation of four members of the ACC synthase gene family in plum. J. Expt. Bot. 59:2009-2027.

Fan, X., S.M. Blankenship, and J.P. Mattheis 1999. 1-MCP inhibits apple ripening. J. Amer. Soc. Hort. Sci. 124:690-695.

Feng, X., A. Apelbaum, E.C. Sisler, and R. Goren. 2000. Control of ethylene responses in avocado fruit with 1-MCP. Postharvest Biol. Technol. 20:143-150.

Golding, J.B., D. Shearer, S.G. Wyllie, and W.B. Mcglasson. 1998. Application of 1-MCP and propylene to identify ethylene-dependent ripening processes in mature banana fruit. Postharvest Biol. Technol. 14:87-98.

Graddick, C., F.M. Basiouny, and M. Burns. 1986. Effects of ethylene, metabolic, and transpiration inhibitors on prolonging the shelf-life of rabbiteye blueberry (Vaccinium ashei Reade). Proc. of the Florida State Horticultural Society. 99:203-205.

Hoeberichts, F.A., L.H.W. Van Der Plas, and E.J. Woltering. 2002. Ethylene perception is required for the expression of tomato ripeningrelated genes and associated -physiological changes even at advanced stages of ripening. Postharvest Biol. Technol. 26:125-133.

Hudson, D.E. and W.H. Tietjen. 1981. Effects of cooling rate on shelflife and decay of highbush blueberries [from anthracnose Gloeosporium, alternaria rot, Alternaria]. HortScience 16:656657.

Janes, H.W., C.-K. Chin, and C. Frenkel. 1978. Respiratory upsurge in blueberries and strawberries as influenced by ethylene and acetaldehyde. Bot. Gaz. 139:50-52.
Jeong, J., J.K. Brecht, D.J. Huber, and S.A. Sargent. 2004. 1-Methylcyclopropene (1-MCP) for maintaining texture quality of fresh-cut tomato. HortScience 39:1359-1362.

Jeong, J., D.J. Huber, and S.A. Sargent. 2003. Delay of avocado (Persea americana) fruit ripening by 1-methylcyclopropene and wax treatments. Postharvest Biol. Technol. 28:247-257.

Jiang, Y., D.C. Joyce, and A.J. Macnish. 1999. Extension of the shelf life of banana fruit by 1-MCP in combination with polyethylene bags. Postharvest Biol. Technol. 16:187-193.

Lipe, J.A. 1978. Ethylene in fruits of blackberry and rabbiteye blueberry. J. Amer. Soc. Hort. Sci. 103:76-77.

Miller, W.R., R.E. McDonald, C.F. Melvin, and K.A. Munroe. 1984. Effect of package type and storage time-temperature on weight loss, firmness, and spoilage of rabbiteye blueberries. J. Amer. Soc. Hort. Sci. 19:638-640.

Mullins, E.D., T.G. McCollum, and R.E. McDonald. 2000. Consequences of ethylene metabolism of inactivating the ethylene receptor sites of diseased non-climacteric fruit. Postharvest Biol. Technol. 19:155-164.

NeSmith, D.S., A. Nunez-Barrios, S.E. Prussia, and D. Aggarwal. 2005. Postharvest berry quality of six rabbiteye blueberry cultivars in response to temperature. J. Amer. Pomol. Soc. 59:13-17.

NeSmith, D.S., S.E. Prussia, M.K. Tetteh, and G. Krewer. 2002. Firmness losses of rabbiteye blueberries (Vaccinium ashei Reade) during harvest and handling. Acta Hort. 574:287-293.

Rohrbach, R.P. and C.M. Mainland. 1987. Blueberry fruit quality as affected by variety. Proc. of the 21st Annual Open House Southeastern Blueberry Council. 21:34-45.

Sanford, K.A., P.D. Lidster, K.B. McRae, E.D. Jackson, R.A. Lawrence, R. Stark, and R.K. Prange. 1991. Lowbush blueberry quality changes in response to mechanical damage and storage temperature. J. Amer. Soc. Hort. Sci. 116:47-51.

Sisler, E.C. and M. Serek. 1997. Inhibitors of ethylene responses in plants at the receptor level: Recent developments. Physiol. Plant. 100:577582.

Sisler, E.C., M. Serek, and E. Dupille. 1996. Comparison of cyclopropene, 1-MCP and 3,3diMCP as ethylene antagonists in plants. Plant Growth Regulat. 18:169-174.

Suzuki, A., T. Kikuchi, and K. Aoba. 1997. Changes in ethylene evolution, ACC content, ethylene forming enzyme activity and respiration in fruits of highbush blueberry. J. Jpn. Soc. Hort. Sci. 66:23-27.

Tetteh, M.K., S.E. Prussia, D.S. Nesmith, B.P. Verma, and D. Aggarwal. 2004. Modeling blueberry firmness and mass loss during cooling delays and storage. Trans. ASAE 47:1121-1127.

Tian, M.S., S. Prakash, H.J. Elgar, H. Young, D.M. Burmeister, and G.S. Ross. 2000. Responses of strawberry fruit to 1-methylcyclopropene (1$\mathrm{MCP})$ and ethylene. Plant Growth Regulat. 32:83-90.

Watkins, C.B. 2006. The use of 1-methylcyclopropene (1-MCP) on fruits and vegetables. Biotechnol. Adv. 24:389-409.

Zheng, Y.H., C.Y. Wang, S.Y. Wang, and W. Zheng. 2003. Effect of high-oxygen atmospheres on blueberry phenolics, anthocyanins, and antioxidant capacity. J. Agr. Food Chem. 19:7162-7169. 